\title{
Sedimentological, palynological and charcoal analyses of the hydric palustrine sediments from the Lielerai-Kimana wetlands, Kajiado, southern Kenya
}

\author{
Esther N. Githumbi ${ }^{1}$ \\ Department of Physical Geography and Ecosystem Science, Lund University, \\ Lund, Sweden \\ Colin J. Courtney Mustaphi \\ Department of Environmental Sciences, Geoecology, University of Basel, \\ Basel, Switzerland \\ Robert Marchant \\ Department of Environment and Geography, Institute for Tropical Ecosystems, \\ University of York, York, United Kingdom
}

\begin{abstract}
Intermittent and sometimes ephemeral wetlands found in savannah ecosystems are subject to complex hydrological and geomorphological processes that influence vegetation and fire patterns, and their use by humans, cattle and wildlife. Today these wetlands are impacted by changes in land use, climate, and wildlife use. Small wetlands in semi-arid climates are dynamic ecosystems that respond rapidly to biological, physical and chemical processes and accumulate sedimentary deposits making them excellent archives of past environmental changes. The Lielerai-Kimana wetlands in the Greater Amboseli Ecosystem of southern Kenya are located within the current protected area network. A $384 \mathrm{~cm}$ long palustrine sediment core was recovered from the Lielerai-Kimana wetlands, radiometrically dated, and used for sedimentological, palynological and charcoal analyses. The ${ }^{210} \mathrm{~Pb}(\mathrm{n}=16$ ages $)$ and ${ }^{14} \mathrm{C}(\mathrm{n}=10$ ages $)$ results suggest a complex depositional pattern covering $c$. 1500 years. The mismatches between ${ }^{210} \mathrm{~Pb}$ and ${ }^{14} \mathrm{C}$ date estimates suggest some degree of sediment mixing which may prevent centennial-scale interpretation of the palaeoenvironmental record. The sediments are characterised by a high silt content from
\end{abstract}

\footnotetext{
${ }^{1}$ Other affiliation: Department of Biology and Environmental Science, Linnaeus University, Kalmar, Sweden ${ }^{2}$ Other affiliation: Water Infrastructure and Sustainable Energy (WISE) Futures, Nelson Mandela African Institution of Science \& Technology, Tengeru, Arusha, Tanzania; and York Institute for Tropical Ecosystems, Department of Environment and Geography, University of York, York, United Kingdom
} 
1500-600 cal yr BP with the organic content increasing from $600 \mathrm{cal}$ yr BP to the present. The pollen data show little changes in vegetation composition, suggesting a mosaic of savannah, woody savannah, riparian, and montane forest persisted throughout the period of deposition. Charcoal and organic content suggest the continuous presence of herbaceous fuels at the coring site from $600 \mathrm{cal}$ yr BP to the present. The results highlight the spatiotemporal heterogeneity and complexity of wetland records across the semi-arid landscapes of Amboseli during the Late Holocene. Further studies on hydroclimate and vegetation change, disturbance ecology (fire, erosion, bioturbation), and human-environment interactions would further develop our understanding of the environmental history and drivers of environmental change across these ecosystems that are increasingly under human land use pressures.

\subsection{INTRODUCTION}

Amboseli is an important ecosystem in southern Kenya due to its high biodiversity, long history of pastoralism, rapidly developing agricultural potential, and subsequent land-use changes over the past decades. High levels of tourism since the 1960s (Western 1973, 2007; Western et al. 2020) make Amboseli an important contributor to Kenya's gross domestic product (GDP) and the livelihoods of local communities (Hodgson 2000; Makindi 2016). Amboseli has experienced, and continues to experience, wide-scale yet spatially complex habitat changes such as: Vachellia xanthophloea woodland reduction, riparian and wetland fluctuation, introduced agriculture and a proliferation of ruderal plant species (Western and Van Praet 1973). Within semi-arid regions, such as the Amboseli, water is a crucial natural resource and ecosystem service. Changes in livelihood strategies from pastoral to sedentary has led to increased pressure on water resources for farming and irrigation (Okello and Kioko 2011; Wishitemi et al. 2015). Amboseli wetlands are intermittently distributed across the semi-arid savannah landscape and have complex responses to hydroclimate, land-use and land cover changes, defaunation and wildlife management (Meijerink and Wijngaarden 1997). Increased densities of wildlife populations outside protected areas due to fencing along migration corridors (Kenya Wildlife Service 2009; Osipova et al. 2018) and fencing in some of Amboseli's wetlands (Okello and Kioko 2011) has been reported. The Amboseli Ecosystem Management Plan 2008-2018 (Kenya Wildlife Service 2009) and Kenya Wetlands Atlas (MEMR 2012) identified wetlands as an exceptional resource value for the Amboseli ecosystem that are susceptible to rapid and irreversible change with complex social co-benefits and potential negative impacts on biodiversity and conservation. Palaeoenvironmental records developed from wetland ecosystem sedimentary archives can provide a long-term context for modern ecosystem changes and develop data suitable for characterising the wetlands, and their histories, as part of developing evidenced-based support for management (Gillson and Marchant 2014; Githumbi et al. 2020).

The abundance of wetlands in Amboseli enabled five palaeoecological studies, focused on a variety of proxies, to provide information relevant to understanding different aspects of environmental, ecological and human-environment interaction change during the Late Holocene (last c. 4200 years). Understanding how the various wetlands responded to large-scale controls (climate variability) and internal controls (hydrological connectivity, topography) is necessary when utilising wetland palaeoenvironmental records to observe temporal change and compare changes across a landscape. Palynological analyses published from Amboseli wetlands, include Namelok (Rucina et al. 2010) and Esambu, Kimana and Ormakau (Githumbi 2017) and were presented in summary formats for discussion alongside archaeological insights (Githumbi et al. 2018a, Shoemaker 2018) and carbon accumulation in wetlands (Gallego-Sala et al. 2018). The oldest radiocarbon dated published record from the Amboseli wetlands is currently from IndoinyoEsambu, which dates back to $c$. 5000 cal yr BP, while the Namelok record covers the past c. 3000 cal yr BP. The radiocarbon dated sediment core presented here from the Lielerai-Kimana 
dates back to $c .1500$ cal yr BP. Sedimentological, geochronological, palynological and charcoal data from the Lielerai-Kimana sediment core are used to characterise the sediments, explore the limitations and opportunities of the geochronological results, and interpret the pollen and charcoal results. The findings are discussed in relation to the history of wetland dynamics in the Amboseli area of southern Kenya.

\subsubsection{Study site}

Amboseli is located in southern Kenya between the northern base of Kilimanjaro, near the Kenya-Tanzania border, Tsavo West National Park and the Chyulu Hills (Figure 1). A semi-arid savannah and scrubland ecosystems, the Amboseli basin occupies $c .3000 \mathrm{~km}^{2}$ and experiences bimodal rainfall distribution. Rainfall patterns are determined by the African monsoon, which is, in turn, driven by the latitudinal migration of the Intertropical Convergence Zone (ITCZ) and its interaction with more local climate systems and topographic feedbacks (Hulme 1996; Marchant et al. 2007). Precipitation mainly falls in two rainy seasons: March-May and October-December. Average annual precipitation is $586 \mathrm{~mm}_{\text {year }}{ }^{-1}$ although with considerable interannual variation (range 226 to $990 \mathrm{~mm} \mathrm{year}^{-1}$ ) from 1979 to 2009 (Githumbi 2017). An overall increase in temperature (daily minimum and maximum) was observed between 1976 and 2001, however, there was little change in precipitation (Altmann et al. 2002). Today, Amboseli supports a wide range of wildlife including ungulates, carnivores, and birds, that co-exist with pastoralist and agricultural land uses, making it an important wildlife conservation area and designated important bird area (IBA).Several of the wetlands across Amboseli are crucial for wildlife migrations among the network of protected (Kenya Wildlife Service 2009; Osipova et al. 2018), however, with

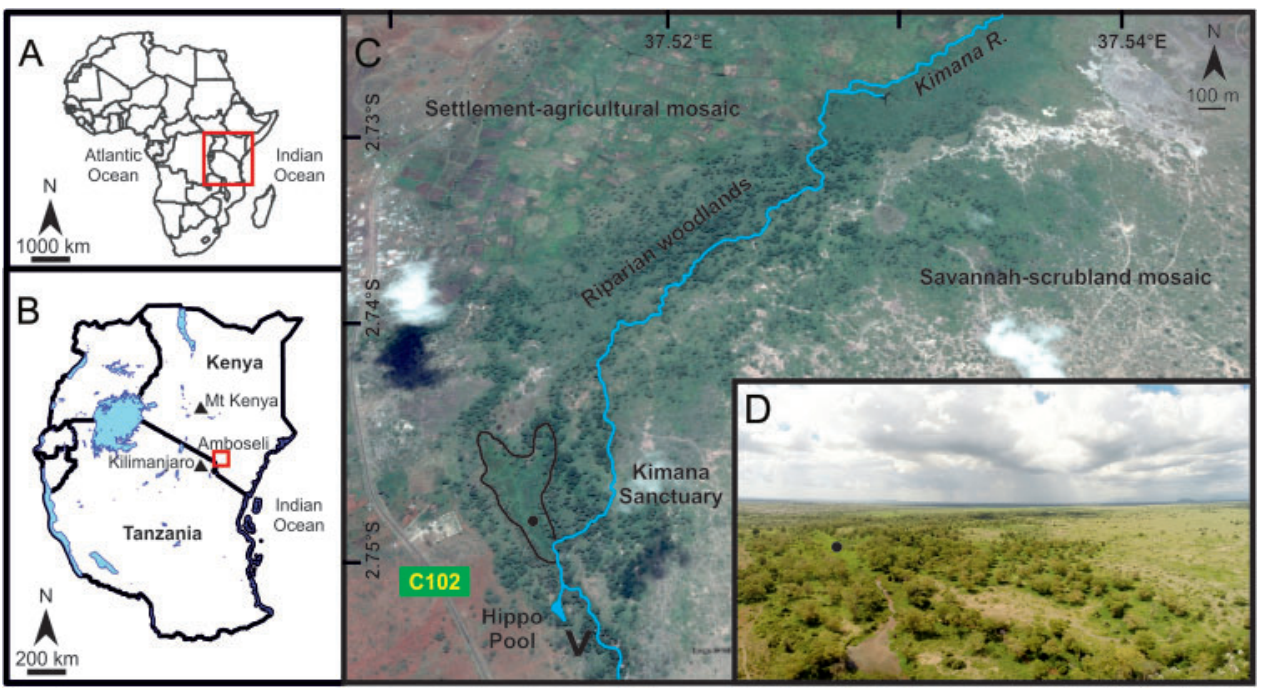

Figure 1. Map of the Lielerai-Kimana wetlands and study site (red boxes). (A) Inset map of Africa and (B) East Africa (C) The Kimana Sanctuary Lielerai-Kimana wetlands and riparian forests along the Kimana River, which flows north and then east. The Cyperaceae and Poaceae covered riparian wetland is outlined with black and the coring location is shown with a black circle (coordinates: $2.748833 \mathrm{~S}, 37.515367 \mathrm{E}, 1222 \mathrm{~m}$ asl). The 'V' symbol indicates the location and perspective of the inset photograph D, and Kenyan road C102. (D) Oblique air photograph of the wetland showing the coring location (black circle) and landscape features around the Kimana Sanctuary protected area (Courtney Mustaphi et al. 2014; Githumbi et al. 2014). Google Earth image dated 27 April 2014 (copyright CNES/Airbus and Google Inc.) Basemap imagery: Google Earth, 2020, http://earth.google.com/web/. 

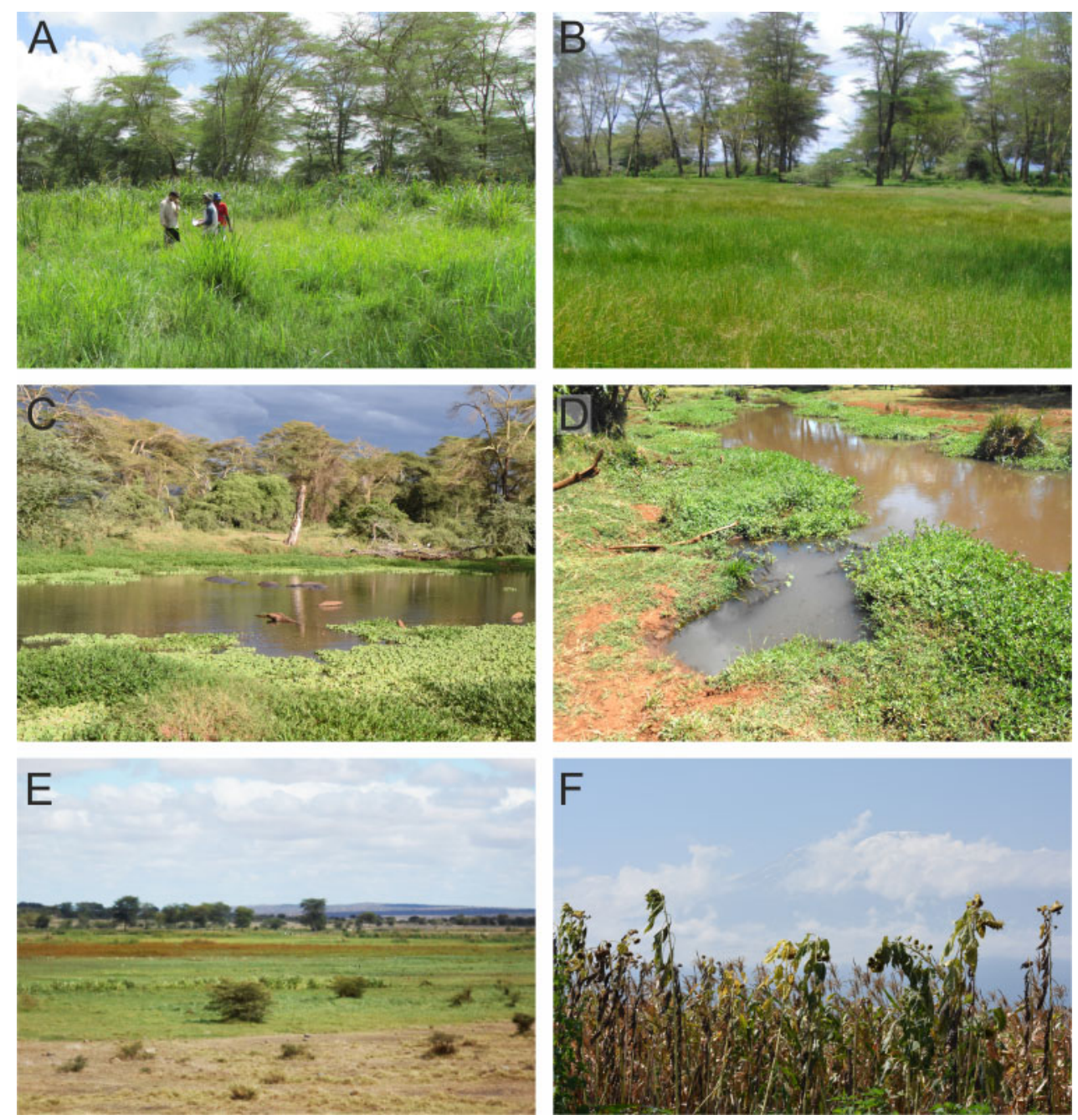

Figure 2. Photographs of landscapes and features around the Kimana wetland. (A) The coring location between the tall Cyperaceae and Poaceae dominated wetland. (B) Short Poaceae and Cyperaceae that cover parts of the southern end of

the Kimana wetland. (C) The Hippo pool (viewed from the west facing southeast). (D) A biogeomorphological riverbank feature heavily influenced by Hippopotamus amphibius and Crocodylus niloticus entering and exiting the Kimana River (flowing to the left of photograph, northward). (E) The eastern margin of the Kimana Sanctuary viewing northeast showing the mosaic of barren ground, savannah, woody savannahs, and wetlands. (F) An example of crops grown in the Amboseli-Oloitoktok area. Photographs: A, Esther Githumbi, April 2014; B, D, E, Colin Mustaphi, March 2015; and C, F, Rob Marchant, March 2015.

increasing anthropogenic land-use pressures and human-wildlife conflicts are increasing (Okello 2005).

The Amboseli landscape comprises of savannah and scrubland plains, lacustrine plains, wetlands, and volcanic footslopes (Meijerink and Wijngaarden 1997). The woody-grassy savannah landscapes are dominated by Pennisetum spp., Cenchrus spp., and African Acacia species (Vachellia and Senegalia, and referred in this paper as Acacias) (Figure 2). The Amboseli wetlands are located on the Kilimanjaro aquifer and they receive groundwater and surface runoff 
primarily from the slopes of Mount Kilimanjaro (Grossmann 2008; Meijerink and Wijngaarden 1997). Amboseli wetlands are either spring fed (Enkongu, Esambu, Ormakau, Namelok) or riverine (Lielerai-Kimana) and highly modified through climatological, biological, geomorphological and hydrological processes. The wetlands overlie deep, well-drained and neutral $\mathrm{pH}$ soils developed from lava flows and partly reworked pyroclastic deposits of Pleistocene age (Williams 1972). These wetland areas are dominated by Cyperus spp. and Sporobolus spp., while Vachellia (Acacias), Balanites, Commiphora, Euphorbia and Syzygium dominate the adjacent woody savannahs and scrublands.

The Lielerai-Kimana toponym comes from the Maa language, where 'Lielerai' refers to the yellow fever trees (Vachellia xanthophloea) and 'Kimana' means 'a continuous circle'. The Lielerai-Kimana wetland is fed by the Kimana River, which flows through the wetlands towards the Chyulu Hills. Parts of the wetland complex was under various forms of protected area status that have included ecotourism and community-based conservation (Githumbi et al. 2018a; Meguro and Inoue 2011) and is an ecological hotspot for wildlife migration and is a hippopotami breeding site.

\subsection{MATERIALS AND METHODS}

\subsubsection{Field methods}

The Lielerai-Kimana core site was located, within the Kimana Sanctuary (also known as Sidai Oleng), at $2.748833^{\circ} \mathrm{S}, 37.5151367^{\circ} \mathrm{E}(1222 \mathrm{~m}$ asl $)$. Today the area around Lielerai-Kimana is a Cyperaceae-covered wetland with hydric soils and palustrine sediments (Figures 2A, 2B). In July 2014 , the profile of the sediments beneath the wetlands were determined through probing using fiberglass rods. A coring location was then chosen where the organic sediment accumulation seemed to be high and sandy layers appeared to be absent. Then the sediments were cored using a hand operated, $50 \mathrm{~cm}$ long, $5 \mathrm{~cm}$ diameter hemicylindrical Russian peat corer (Jowsey 1966). Sediment cores from two overlapping parallel boreholes were obtained. Together the parallel cores contained the complete sedimentary sequence and reached a maximum depth of $384 \mathrm{~cm}$ (Courtney Mustaphi et al. 2014; Githumbi 2017). Upon recovery, the core sections were wrapped in plastic and aluminium foil, and transferred into split plastic PVC pipes for transport. The sediment cores were then transported to the Palynology and Palaeobotany Section of the National Museums of Kenya (NMK; Nairobi, Kenya) where they were placed in cold storage at $4^{\circ} \mathrm{C}$. Subsamples were later extracted at NMK, and analyses were undertaken at NMK and the University of York (UK).

\subsubsection{Laboratory methods}

\subsubsection{Geochronology}

Ten accelerator mass spectrometer (AMS) radiocarbon dates were obtained from the LieleraiKimana sediment core (Table 1). Two bulk sediment subsamples were sent to Direct AMS (Bothell, WA, USA) that were acid-base-acid washed, combusted, graphitised and measured using a National Electrostatics Corporation (NEC) 1.5 SDH Compact Pelletron $500 \mathrm{kV}$ AMS. Two bulk sediment subsamples were sent to the ${ }^{14} \mathrm{CHRONO}$ laboratory (Queen's University Belfast, Northern Ireland) and acid wash pre-treated prior to combustion to $\mathrm{CO}_{2}$, graphitization and AMS using a NEC 0.5 MV compact accelerator. Six sediment subsamples were wet sieved using a $63 \mu \mathrm{m}$ mesh and the fine organic detrital fraction $(<63 \mu \mathrm{m})$ was graphitised and dated at the East Kilbride facility of the SUERC Radiocarbon Laboratory (University of Glasgow) using either the National Electrostatic Corporation $5 \mathrm{MV}$ tandem AMS or $250 \mathrm{kV}$ single-stage AMS. Radiocarbon ages $\left({ }^{14} \mathrm{C}\right.$ years BP) were calibrated using the IntCall 13 curve (Reimer et al. 2013). Calibrated ages are presented in years BP (Before Present, CE 1950) by convention. 
Table 1. Alpha counter radioactivities (counts per second or $\mathrm{Bq}$ ) and CRS model calendar age results of ${ }^{210} \mathrm{~Pb}$ dating the uppermost sediments of the Lielerai-Kimana sediment core collected in CE2014 ( $-64 \mathrm{yr}$ BP). Note that samples below ${ }^{210} \mathrm{~Pb}$ background radioactivities $(34-40 \mathrm{~cm})$ do not produce CRS calendar age estimates. Acronyms: BP, before present AD1950; CRS, constant rate of supply model; NA, not applicable, ages not modelled.

\begin{tabular}{|c|c|c|c|c|c|c|c|c|c|}
\hline $\begin{array}{l}\text { Depth } \\
(\mathrm{cm})\end{array}$ & $\begin{array}{l}\text { Dry } \\
\text { weight } \\
\text { (g) }\end{array}$ & $\begin{array}{l}\text { Bulk } \\
\text { density } \\
\left(\mathrm{g} \mathrm{cm}^{-3}\right)\end{array}$ & $\begin{array}{l}\text { Corrected } \\
\mathrm{d}^{209} \mathrm{Po} \\
\text { (counts) }\end{array}$ & $\begin{array}{l}\text { Corrected } \\
\mathrm{d}^{210} \mathrm{Po} \\
\text { (counts) }\end{array}$ & $\begin{array}{l}{ }^{210} \mathrm{Po} \\
{ }^{209} \mathrm{Po}\end{array}$ & $\begin{array}{l}{ }^{210} \mathrm{~Pb} \\
\text { activity } \\
\left(\mathrm{Bq} \mathrm{kg}^{-1}\right)\end{array}$ & $\begin{array}{l}{ }^{210} \mathrm{~Pb}- \\
\text { activity } \\
\text { error } \pm 1 \sigma \\
\left(\mathrm{Bq} \mathrm{kg}^{-1}\right)\end{array}$ & $\begin{array}{l}\text { CRS } \\
\text { year } \\
\text { BP }\end{array}$ & $\begin{array}{l}\text { CRS } 2 \sigma \\
\text { error } \\
\text { (years) }\end{array}$ \\
\hline $4-5$ & 0.2523 & 0.2678 & 2073.30 & 134.25 & 0.06 & 23.55 & 2.16 & -63 & 2.01 \\
\hline $5-6$ & 0.3035 & 0.3109 & 1654.24 & 95.75 & 0.06 & 17.50 & 1.89 & -62 & 2.29 \\
\hline $6-8$ & 0.502 & 0.2614 & 973.14 & 69.73 & 0.07 & 13.10 & 1.66 & -61 & 2.30 \\
\hline $8-10$ & 0.3801 & 0.2077 & 1760.26 & 88.46 & 0.05 & 12.13 & 1.36 & -60 & 2.31 \\
\hline $10-12$ & 0.4117 & 0.2247 & 1490.22 & 85.34 & 0.06 & 12.77 & 1.46 & -59 & 2.32 \\
\hline $12-14$ & 0.5203 & 0.2864 & 1375.20 & 135.30 & 0.10 & 17.35 & 1.61 & -57 & 2.32 \\
\hline $14-16$ & 0.4018 & 0.2202 & 1434.21 & 88.46 & 0.06 & 14.09 & 1.59 & -55 & 2.34 \\
\hline $16-18$ & 0.3981 & 0.2184 & 1486.22 & 139.46 & 0.09 & 21.63 & 1.97 & -50 & 2.37 \\
\hline $18-20$ & 0.3977 & 0.2347 & 1421.21 & 113.44 & 0.08 & 18.42 & 1.85 & -45 & 2.40 \\
\hline $20-22$ & 0.4735 & 0.2839 & 1999.29 & 218.55 & 0.11 & 21.19 & 1.57 & -38 & 2.45 \\
\hline $22-24$ & 0.3152 & 0.2079 & 1768.26 & 150.91 & 0.09 & 24.85 & 2.17 & -24 & 2.58 \\
\hline $24-26$ & 0.3312 & 0.1887 & 1197.18 & 53.08 & 0.04 & 12.28 & 1.77 & -15 & 2.65 \\
\hline $26-28$ & 0.2737 & 0.1577 & 1147.17 & 53.08 & 0.05 & 15.51 & 2.23 & 4 & 3.01 \\
\hline $28-30$ & 0.1683 & 0.1607 & 1163.17 & 18.73 & 0.02 & 8.78 & 2.09 & 20 & 3.36 \\
\hline $30-32$ & 0.2761 & 0.1824 & 1835.27 & 38.51 & 0.02 & 6.97 & 1.16 & 37 & 3.84 \\
\hline $32-34$ & 0.2236 & 0.1541 & 1430.21 & 23.94 & 0.02 & 6.87 & 1.45 & 79 & 7.24 \\
\hline $34-36$ & 0.2231 & 0.1345 & 1341.20 & 15.61 & 0.01 & 4.79 & 1.24 & NA & NA \\
\hline $36-38$ & 0.2042 & 0.1272 & 1170.17 & 9.37 & 0.01 & 3.60 & 1.2 & NA & NA \\
\hline $38-40$ & 0.2425 & 0.1589 & 1567.23 & 18.73 & 0.01 & 4.52 & 1.07 & NA & NA \\
\hline
\end{tabular}

Lead $\left({ }^{210} \mathrm{~Pb}\right)$ dating of the uppermost sediments was done by drying sediment subsamples from intervals between 4-40 cm depth and measured through alpha spectroscopy at the University of Exeter, UK. A constant rate of supply (CRS) model of calendar age estimates with age estimate errors that have a Gaussian distribution (Appleby 2005) was developed with the core top $(0 \mathrm{~cm})$ set as -64 years $\mathrm{BP}$, the year of core collection. ${ }^{210} \mathrm{~Pb}$ background activities were reached at 34-36 cm depth.

An age-depth model combining both calibrated ${ }^{14} \mathrm{C}$ and ${ }^{210} \mathrm{~Pb}$ ages was developed using Bacon (Blaauw and Christen 2011) in RStudio version 1.3.959.

\subsubsection{Sedimentological characterisation}

The Lielerai-Kimana sediment cores were longitudinally split and surfaces cleaned flat with a knife and the composite stratigraphy of overlapping core drives was established in the laboratory. The cores were scanned at BOSCORF National Oceanography Centre (NOC), Southampton, UK, using a molybdenum tube ITRAX ${ }^{\mathrm{TM}}$ Core Scanner for $\mu$ XRF semi-quantification of 36 elements at $500 \mu \mathrm{m}$ resolution (Croudace and Rothwell 2015). The X-ray beam irradiated the centerline of the core using a $3 \mathrm{~kW}$ Mo X-ray tube typically run at $55 \mathrm{kV}$ and 50 ma for $\mathrm{X}$-radiography and $30 \mathrm{kV}$ and 50 ma for the XRF scan. A Geotek multi-sensor core logger (MSCL-XYZ) with a Bartington MS2E magnetic susceptibility point sensor and a Konica Minolta spectrophotometer (quantified greyscale reflectance) scanned the cores at $0.5 \mathrm{~cm}$ intervals from $0-384 \mathrm{~cm}$ stratigraphic depth. 
Loss-on-ignition (LOI) analysis (Heiri et al. 2001) was used to estimate organic matter content, carbonate content and residuals mean clastic particle size every $5 \mathrm{~cm}$ down core. Wet sediment subsamples were weighed dried at $105^{\circ} \mathrm{C}$ for 24 hours, then burned at $550^{\circ} \mathrm{C}$ for 5 hours and weighed, and ashed at $950^{\circ} \mathrm{C}$ for 3 hours and weighed, to calculate the dry weight (and dry bulk density), organic matter and carbonate contents respectively. Particle size distribution analysis used the Malvern Mastersizer 2000 laser granulometer (MEH/MJG180914). The binned particle size distributions were aggregated into percentage clay $(<1-4 \mu \mathrm{m})$, silt $(4-63 \mu \mathrm{m})$, and sand $(63-2000 \mu \mathrm{m})$ fractions (Blott and Pye 2012). Bulk sediment C:N ratios for the top $111-0 \mathrm{~cm}$ at contiguous 1-cm intervals were measured using a CHN analyser at the University of Exeter, UK.

\subsubsection{Sieved (>125 $\mu \mathrm{m})$ charcoal analysis}

For sieved charcoal analysis, subsamples of $1 \mathrm{~cm}^{3}$ of wet sediment were removed at a continuous $1 \mathrm{~cm}$ resolution. Samples were soaked in a sodium metaphosphate solution (Tsakiridou et al. 2020) for $>24$ hours and then wet sieved through a $125-\mu \mathrm{m}$ mesh and the larger fraction was transferred to a gridded Petri dish. Charcoal pieces were identified and total charcoal was tallied through visual inspection and manipulated with a metal probing needle under a Zeiss Stemi 2000-C optical stereo microscope at 10-40 × magnifications and converted to sieved charcoal concentrations (pieces $\mathrm{cm}^{-3}$ ).

\subsubsection{Pollen preparation and analysis}

Wet sediment subsamples of $1 \mathrm{~cm}^{3}$ were extracted from the core at $20-\mathrm{cm}$ intervals and processed for pollen analysis using sequential sediment digestions (Fægri and Iversen 1989). One tablet of exotic Lycopodium spores was added prior to pollen processing to act as a counter for calculating pollen concentration or estimation of absolute influx (Lund University batch number 3862 , exotic count per tablet: $9666 \pm 212.3$ ). Subsamples were chemically digested, centrifuged, decanted, and rinsed with deionised water (or glacial acetic acid) after each digestion step. The digestion step included 10\% $\mathrm{HCl}$ (room temperature), 10\% $\mathrm{KOH}$ (room temperature), $50 \% \mathrm{HF}$ $\left(70^{\circ} \mathrm{C}\right)$, dewatering with glacial acetic acid, and acetolysis (Erdtman 1960; Fægri and Iversen 1989). Digested sediment residues were transferred into vials using $96 \%$ ethanol, centrifuged and decanted. Glycerine was added to match the volume of residue and then left for the ethanol to evaporate in an oven at $60^{\circ} \mathrm{C}$ then a droplet was mounted on standard microscope slides with a coverslip (Bennett and Willis 2001).

Pollen counts were conducted across horizontal line scans of the coverslips using a Leica DM4000B microscope at a magnification of $400 \times$. Identifications were confirmed using a reference collection derived from pollen and herbarium specimens from the National Museums of Kenya and published pollen atlases (Bonnefille and Riollet 1980; Hamilton 1976, 1982; Hamilton and Perrott 1980; Schüler et al. 2014). Pollen diagrams were plotted using C2 v.1.7.6 (Juggins 2003). The stratigraphically constrained cluster analysis using incremental sum of squares (CONISS, Grimm 1987) was used to delimit statistically significant assemblage zones of the relative abundances of all pollen types using a broken stick test (Bennett 1996). Pollen were grouped using published pollen atlases (Schüler and Hemp 2016), previously published pollen grouping (Githumbi et al. 2018a; Rucina et al. 2010), field observation of taxa, and ecology and habitat descriptions (Dharani 2011).

\subsection{RESULTS}

\subsubsection{Chronology and stratigraphy}

In total sixteen ${ }^{210} \mathrm{~Pb}$ (Table 1) and 10 AMS radiocarbon dates (Table 2) were used in the development of the Bacon age-depth model (Figure 3; Blaauw and Christen 2011). The ${ }^{210} \mathrm{~Pb}$ samples 
Table 2. Reported AMS radiocarbon dates with IntCal13 calibrated ages with maximum $2 \sigma$ error range (year BP, before present; Reimer et al. 2013) from the Lielerai-Kimana sediment core.

\begin{tabular}{lllll}
\hline $\begin{array}{l}\text { Depth } \\
(\mathrm{cm})\end{array}$ & Lab code & $\begin{array}{l}\text { Age } \\
\left({ }^{14} \text { C years }\right)\end{array}$ & $\begin{array}{l}\text { Calibrated age } \\
(\text { year BP })\end{array}$ & Material \\
\hline $20-21$ & SUERC-64044 & $578 \pm 37$ & $600 \pm 73$ & $<63 \mu \mathrm{m}$ sieved organic detritus \\
$40-41$ & SUERC-64045 & $526 \pm 37$ & $539 \pm 88$ & $<63 \mu \mathrm{m}$ sieved organic detritus \\
$50-51$ & SUERC-57339 & $424 \pm 37$ & $486 \pm 158$ & $<63 \mu \mathrm{m}$ sieved organic detritus \\
$50-51$ & SUERC-58881 & $500 \pm 37$ & $527 \pm 96$ & $<63 \mu \mathrm{m}$ sieved organic detritus \\
$75-76$ & SUERC-64046 & $647 \pm 37$ & $605 \pm 64$ & $<63 \mu \mathrm{m}$ sieved organic detritus \\
$100-101$ & UBA-26122 & $540 \pm 24$ & $543 \pm 81$ & bulk sediment \\
$100-101$ & SUERC-64047 & $630 \pm 35$ & $602 \pm 58$ & $<63 \mu \mathrm{m}$ sieved organic detritus \\
$260-261$ & D-AMS 009667 & $946 \pm 25$ & $850 \pm 67$ & bulk sediment \\
$310-311$ & D-AMS 009668 & $455 \pm 24$ & $509 \pm 27$ & bulk sediment \\
$370-371$ & UBA-26122 & $1458 \pm 31$ & $1340 \pm 44$ & bulk sediment \\
\hline
\end{tabular}

were from the top $40 \mathrm{~cm}$ of the core and the AMS radiocarbon dates ranged from the whole core. There is a high degree of uncertainty in the age-depth model from 650-100 cal yr BP due to the range of dates in this uppermost section, suggesting some degree of movement of old carbon.

The Lielerai-Kimana core was predominantly organic rich (c. 20\%), poorly sorted, sandy and coarse silt sediments (c. $61 \%$ silt, c. $23 \%$ sand and c. $11 \%$ clay) and three broad lithological units were observed (Figure 4). The base of the core $(384 \mathrm{~cm})$ to $380 \mathrm{~cm}$ contained very poorly sorted dark grey sandy and coarse silts (mean particle size 70-170 $\mu \mathrm{m}$ ) with light coloured sandy laminations. The second unit from $380-103 \mathrm{~cm}$ was a massive, visually homogeneous, poorly sorted, very dark brown organic sediment (10-25\%), with increased clay content and less sand content (mean particle size $23-250 \mu \mathrm{m}$ ). The uppermost unit, from $103 \mathrm{~cm}$ to the top, contained very poorly sorted, medium dark brown sandy silt (mean particle size $80-250 \mu \mathrm{m}$ ) with a very high organic content (40-90\%). C/N values were relatively high and variable within the measured section (Figure 3), $111-0 \mathrm{~cm}$ depth, carbon ranged in value between $16 \%$ and $48 \%$ while nitrogen ranged between $0.6 \%$ and $1.2 \%$, the three $\mathrm{C} / \mathrm{N}$ peaks are observed at $32 \mathrm{~cm}, 44 \mathrm{~cm}$ and $86 \mathrm{~cm}$. Magnetic susceptibility ranges from 0 to $617.41 \kappa$ with a mean of $191.45 \kappa$.

\subsubsection{Charcoal}

Sieved charcoal particle $(>125 \mu \mathrm{m})$ concentrations ranged $2-5700$ pieces $\mathrm{cm}^{3}$ with a mean of 329 (median of 104 pieces $\mathrm{cm}^{3}$ ) and $1 \sigma$ standard deviation of 656 . Throughout the core, but particularly in the uppermost section the charcoal concentrations are highly variable. Charcoal concentrations were generally $<200$ pieces $\mathrm{cm}^{3}$ from $384-100 \mathrm{~cm}$ and averaged 1000 pieces $\mathrm{cm}^{3}$ from 100-20 cm. Charcoal concentrations were $<1000$ pieces $\mathrm{cm}^{3}$ from $20-0 \mathrm{~cm}$ (Figure 4 ). When the charcoal concentrations were converted to charcoal accumulation rates (influx, pieces $\mathrm{cm}^{2}$ year ${ }^{1}$ ), the pattern is very similar to the concentration values, with the exception of a slight increase in the top $30 \mathrm{~cm}$ that is not evident in the concentration values. Several surface sediment samples of $0-1 \mathrm{~cm}$ depth from different parts of the swamp $(\mathrm{n}=13)$ were analysed using the same charcoal sieving method and averaged 17 pieces $\mathrm{cm}^{3}$ with a range of $0-162$ pieces $\mathrm{cm}^{-3}$. The conspicuous increase in charcoal around $100 \mathrm{~cm}$ is concomitant with increased organic content and sands, and changes to the elemental composition measured by ITRAX (Figure 4). 


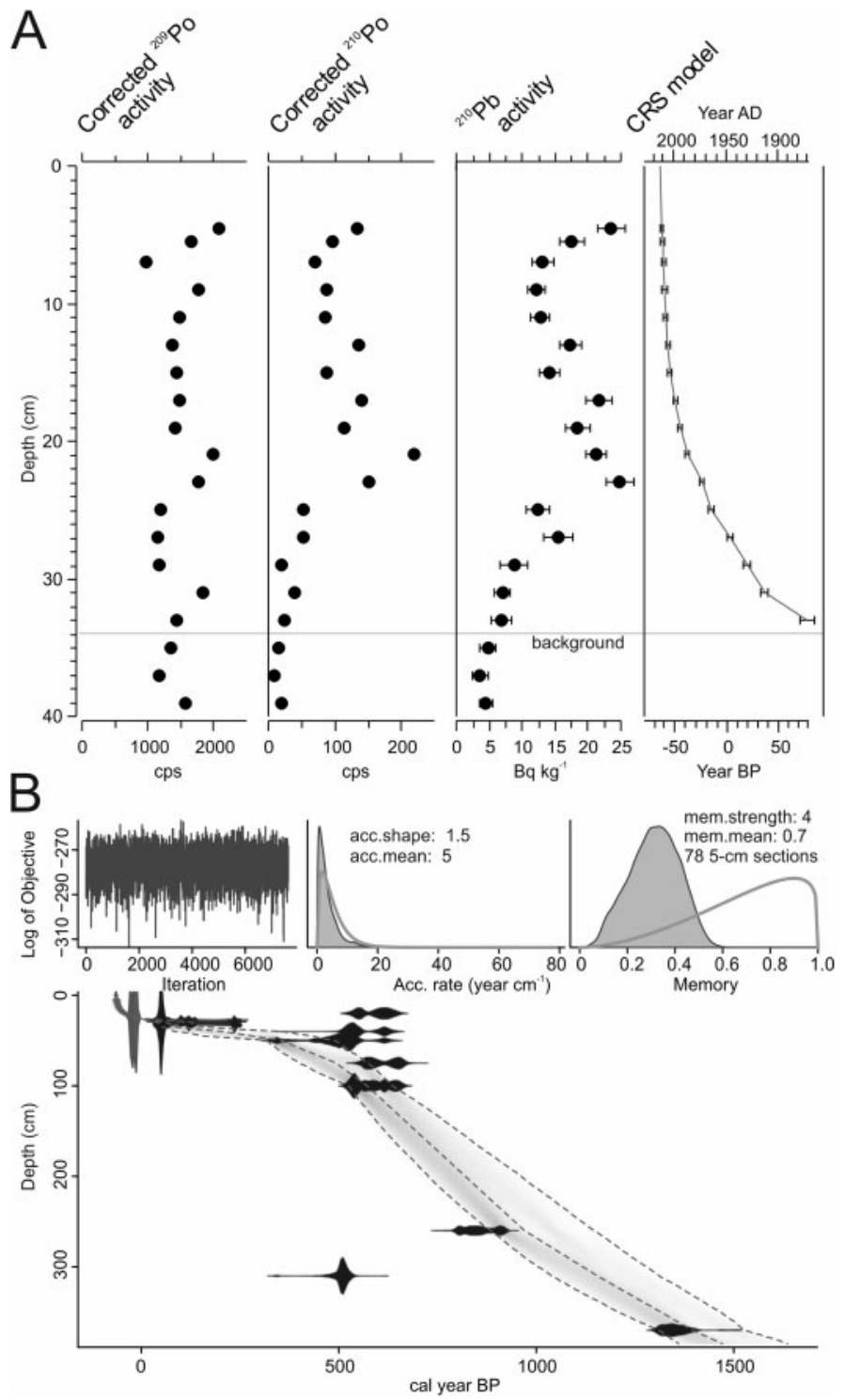

Figure 3. (A) Alpha radioactivities and CRS model calendar age estimates (years BP) of the uppermost sediments of the Kimana sediment core. (B) Age-depth model iteration using IntCal13 calibration curve and default BACON settings.

\subsubsection{Pollen}

Forty-six pollen taxa were identified from the Lielerai-Kimana sediment core and pollen-slide charcoal was also counted. Although the apparent variability of pollen relative abundances is relatively low, the CONISS zonation identified two significant pollen zones and the dendrogram showed insignificant zone breaks (subzones; Figure 5). The pollen taxa have been ordered by dominant growth form in Figure 5. The pollen assemblages are similar throughout the past 1500 


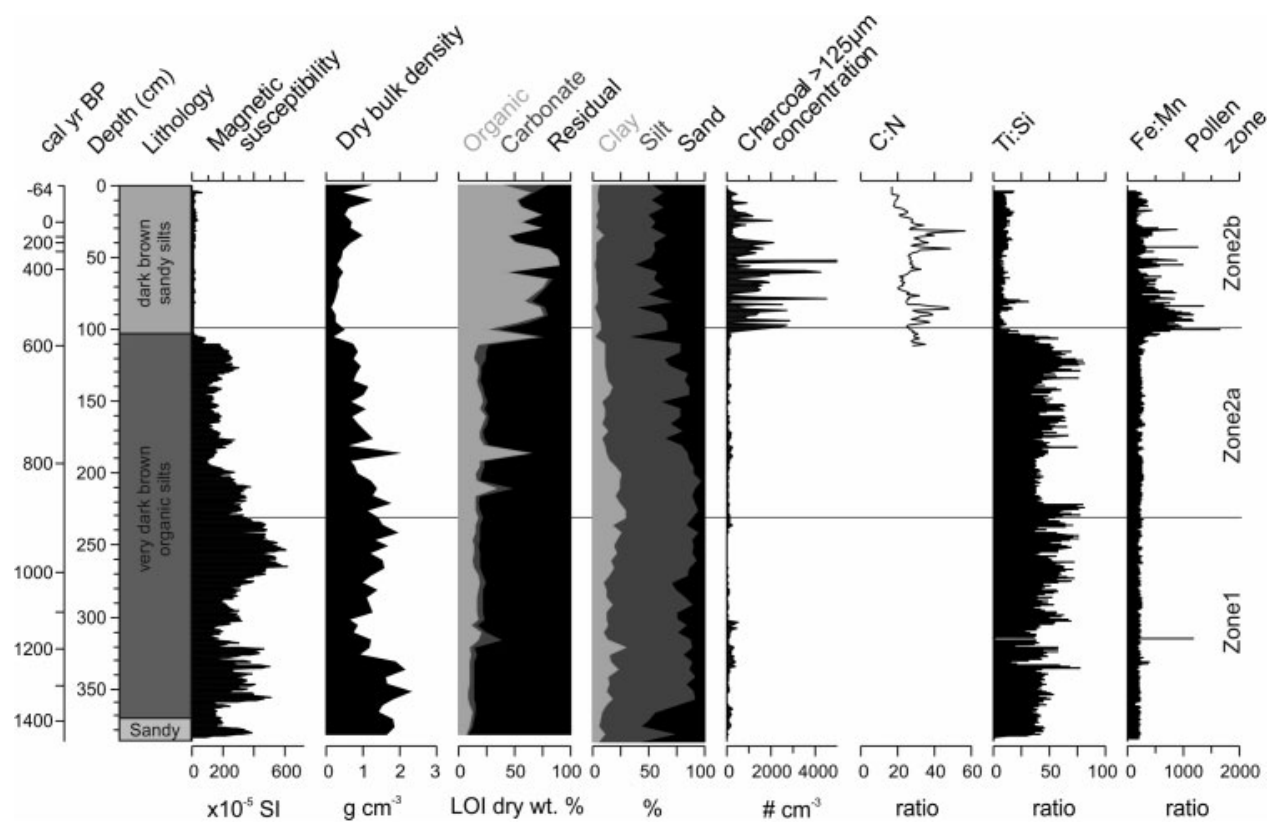

Figure 4. Sedimentological results of the Kimana wetland sediment core and age-depth model estimated downcore ages (at left). The visual lithological description and sediment characterisation measurements of volume magnetic susceptibility, dry sediment bulk density, and loss-on-ignition results, particle size distribution summary and charcoal concentrations. C:N measurements were collected for the top 111-0 cm. Elemental ratios were calculated from ITRAX XRD results (cps units). Pollen zones delineated by horizontal lines from CONISS analysis of the pollen relative abundances (see Figure 5).

years, consistent with the current savannah, wooded savannah, and riparian vegetation surrounding the site. Throughout the record the trees and shrubs have a combined mean value of $c .50 \%$, c. $24 \%$ and c. $26 \%$. The herbaceous taxa are c. $31 \%$, the aquatics $c .12 \%$ and the grass $c .6 \%$. The dominating taxa occurring above $>2 \%$ throughout the record are Vachelia (Acacia) c. 3\%, Carissa c. 2\%, Polyscias c. 2\%, Balanites c. 2\%, Podocarpus c. 3\%, Euphorbia c. 3\%, Commelina c. 3.7\%, Commiphora c. 2.6\%, Asteraceae c. 2.8\%, Amaranthaceae c. 2.6\%, Cyperaceae c. $7 \%$, Typha c. $3.5 \%$ and Poaceae c. 5\%. The lowermost significant pollen assemblage zone 1 , from the core bottom to $c$. $900 \mathrm{cal}$ yr BP $(385$ to $230 \mathrm{~cm}$ ) has tree pollen abundances of $c$. $24 \%$, shrub pollen $c .27 \%$, herbs $c .31 \%$, aquatics $c .12 \%$ and grasses $c .6 \%$. The uppermost significant pollen assemblage zone 2 , from $c .900 \mathrm{cal} \mathrm{yr}$ BP to present $(230 \mathrm{~cm}$ to the top) is divided into two subzones: zone $2 \mathrm{a}$ (from $c$. 800-500 cal yr BP, 230-90 cm) with tree pollen abundances of c. $24 \%$, c. $27 \%$ shrub pollen, c. $31 \%$ herbs, c. $12 \%$ aquatics and grasses $c$. $6 \%$. The topmost subzone $2 \mathrm{~b}$ (from $c$. $500 \mathrm{cal}$ yr BP to present, $90-0 \mathrm{~cm}$ ) shows tree pollen abundances of $c .26 \%$, c. $25 \%$ shrub pollen, c. $31 \%$ herbs, c. $12 \%$ aquatics, and c. $6 \%$ grasses.

\subsection{DISCUSSION}

\subsubsection{Sedimentology and chronology}

The poorly sorted sediments and high sand content suggest complex transport and depositional energy regimes influence the sediment deposition into the Lielerai-Kimana wetland. The wetland is under high bioturbation pressure from microorganisms, herbivores and has a river running 


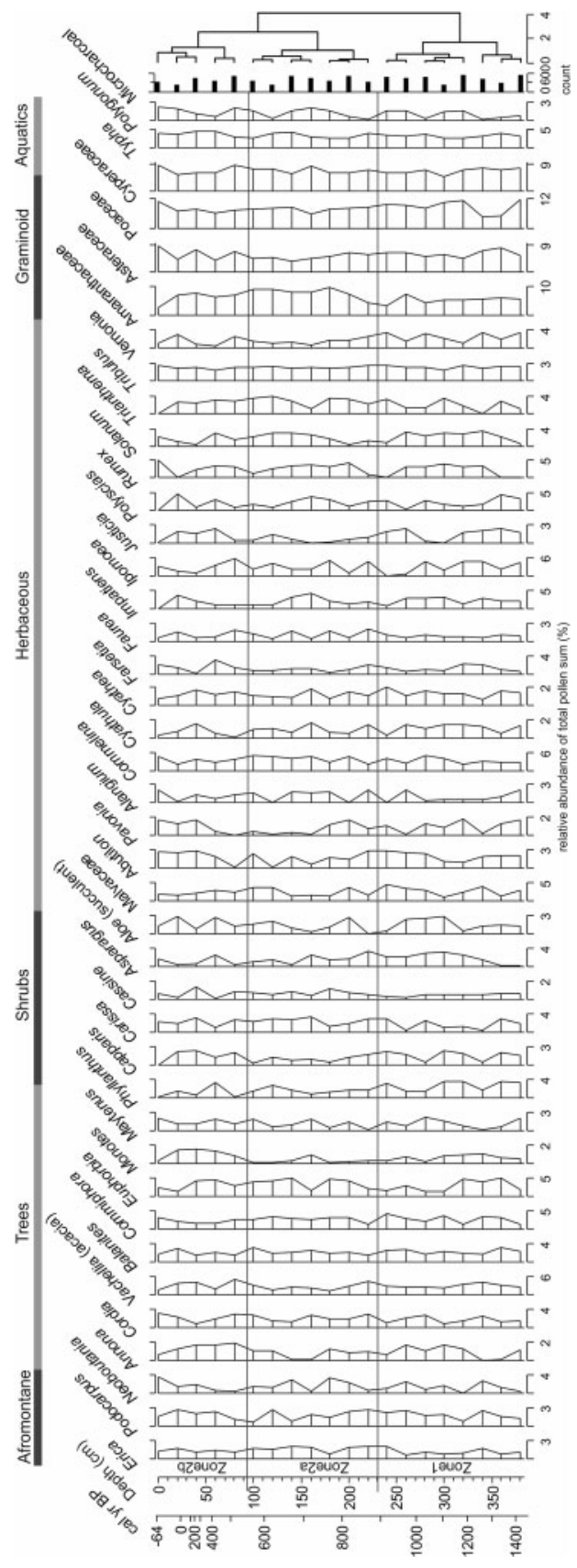

Figure 5. Relative abundance of the total pollen sum. Select taxa shown. Pollen groups based on qualitative predominance of taxa or structural growth forms in the Amboseli area (Githumbi et al. 2018a and 2018b; Rucina et al. 2010 ) with succulents shown in brackets. CONISS zonation with 1 statistically significant zone break and 1 insignificant zone bound between zone $2 \mathrm{a}$ and $2 \mathrm{~b}$ (CONISS dendrogram units not shown; total sum of squares $\times 1000$ ). 
through the wetland that ephemerally floods. From the base of the core $(384 \mathrm{~cm})$ up to $100 \mathrm{~cm}$, the sediments are characterised by moderate organic, high silt, and higher clay content. This could reflect the ephemeral nature of the catchment that is fed by a river with the headwaters in the nearby Kilimanjaro mountain. The low $(<20 \%)$ organic content measured in the lower half of the core (384-200 cm; Figure 4) is similar to organic content measured from modern hippopotamus pool margins, trails and mudflats inside the Ngorongoro Crater (Deocampo 2002); although, Ngorongoro crater wetlands are generally much larger and far less shaded by trees than is currently found at Lielerai-Kimana. In the uppermost unit (100 $\mathrm{cm}$ to the top; Figure 4), the magnetic susceptibility drops significantly, we observe a high Fe:Mn ratio, low Ti:Si ratio, high organic, charcoal and sand content. The radiocarbon ages suggest a high degree of remobilisation of organic content from within the catchment aged between 650-400 cal yr BP. It is frequently observed that organic matter (including charcoal after fires) and sands at the surface are transported by surface sheet wash during intense rain events on top of the very hard compacted soils (see also Shoemaker 2018, page 61). These materials could be transported into the riverine and palustrine features from the wider Amboseli landscape and trapped by vegetation (Courtney Mustaphi et al. 2015; Koff and Vandel 2008). Within the top $100 \mathrm{~cm}$ (Figure 3) the $\mathrm{C} / \mathrm{N}$ values are very high and variable, indicative of terrestrial sources and the high variability may be due to certain layers, such as $30-50 \mathrm{~cm}$ and around $100 \mathrm{~cm}$, having high rates of microbial activity.

Bulk sediment radiocarbon dates can produce older ${ }^{14} \mathrm{C}$ dates because of aggregation of remobilised fine organic matter from the catchment and have a lower precision (Barnekow et al. 1998; Grimm et al. 2009). Bulk sediment offsets have not been explicitly investigated in wetland ecosystems in eastern Africa. The Lielerai-Kimana record at $101-100 \mathrm{~cm}$ provides one example of a comparison for a bulk sediment age estimate of $540 \pm 24$ (UBA-26122; Figure 3) and $<63$ um sieved organic detritus age of $630 \pm 35$ (SUERC-64047). In this example, the age of the finer organic detritus was older than the total bulk sediment (with visible rootlets removed). In palustrine sediments, rootlet remains need to be avoided because of vertical movement of carbon in the stratigraphy. The offset could be due to a remainder of younger fine rootlets persisting in the bulk sediment sample, remobilised clay- and silt-sized organics in the catchment or remobilised organics with a variety of radiocarbon ages deposited together - with the limited comparable results, here it is difficult to discern the cause.

The distribution of the radiocarbon samples is less monotonic and not in stratigraphic superposition; but overall, there is a tendency towards older dates (1500-940 cal yr BP) towards the bottom of the core. The ${ }^{210} \mathrm{~Pb}$ profile has some evidence of disturbed sediments over the past century, but is not completely mixed or noisy, and there are large offsets of around 400 years, between the ${ }^{210} \mathrm{~Pb}$ and ${ }^{14} \mathrm{C}$ radiometric dates. Offsets between radiocarbon dating of organic content and ${ }^{210} \mathrm{~Pb}$ dating of the uppermost clastic sediments has been observed in sediments from temperature lacustrine deposits with the potential for remobilisation of older organic detritus in the catchment (Rinta et al. 2016). In nearby volcanic Crater Lake Duluti, Mount Meru, century-scale disparities between the ${ }^{210} \mathrm{~Pb}$ age estimates and radiocarbon ages occurred in the top sediments (Öberg et al. 2012). This could be due to changing sedimentation from within the closed catchment of the crater due to land use and change cover change, and as varying water levels influencing the submerged macrophyte coverage and resuspension and deposition of organic sediments (Öberg et al. 2013).

The top of the record presented a reasonable curve of higher ${ }^{210} \mathrm{~Pb}$ alpha radioactivities that decreased and reached a background activity by $34 \mathrm{~cm}$ depth; yet, the radioactivities suggest a slight some degree of sediment mixing from 23 to $7 \mathrm{~cm}$ (Figure 3A). The uppermost radiocarbon ages are several centuries older than the ${ }^{210} \mathrm{~Pb}$ age estimates suggesting reworking of carbon from within the catchment for bulk and fine $(<63 \mu \mathrm{m})$ organic matter. Potential causes include riverine overbank flow (wetland is located close to Kimana river), deposition of sediments and organic matter from the catchment, vegetation bioturbation through root establishment, and mammalian 
bioturbation (the wetland is a key watering point for Amboseli wildlife and a Hippo pool). This may prevent centennial-scale interpretation of the palaeoenvironmental record. A combination

of ${ }^{210} \mathrm{~Pb}$ and radiocarbon dates at the top of our record improves the utility of the age-depth model by highlighting the influx of old and material. The proximity of Lielarai-Kimana wetland to Kimana River could be the main driver of the influx observed where flooding of the river and use of the wetland by the resident hippos is a constant source of sediment flow.

\subsubsection{Regional palaeoenvironmental records}

Several wetlands in the region have basal ages from 3000-1500 cal yr BP, suggesting a phase of wetland establishment and maintenance by hydroclimatic, topographical/geological (Liutkus and Ashley 2003; Owen et al. 2004), and biogeomorphological processes (Deocampo 2002; McCarthy et al. 1998). Palustrine sediments from the Amboseli and Tsavo areas have basal radiocarbon dates $>5000$ cal yr BP (Gillson 2004; Githumbi et al. 2018a; Rucina et al. 2010). Esambu had an older radiocarbon date of $c .5000 \mathrm{cal} \mathrm{yr} \mathrm{BP,} \mathrm{and} \mathrm{the} \mathrm{sediments} \mathrm{at} \mathrm{this}$ age were highly represented dry savannah pollen types, such as Vachellia (acacia) and Amaranthaceae/Chenopodiaceae as opposed to wetland taxa (Githumbi et al. 2018b). That suggests the landscape was an open patchy savannah where the lack of herbaceous vegetation or a continuous understory indicates a dry period and that the dimensions and spatial distribution of the hydric palustrine ecosystems within the semi-arid ecosystem varies through time in response to hydroclimatic, topographical, and biogeomorphological processes (Ashley et al. 2002, Casanova and Powling 2015; Jolly et al. 2008). Sediment cores collected from relatively small, montane wetlands in adjacent highland areas have similar basal ages (5000-1500 cal yr BP), including Kilimanjaro (Coetzee 1967; Courtney Mustaphi et al. 2020; Hamilton 1982), North Pare Mountains (Heckmann 2014), and Mount Shengena (Finch et al. 2017). The Late Holocene in this region was characterised by intermittent drought phases following the end of the African Humid Period (Verschuren et al. 2009) that influenced the vegetation and fire regimes of the savannahs (Gillson 2004; Nelson et al. 2012; Urban et al. 2015). The stability of wetland vegetation has been described in coastal wetlands of eastern South Africa during the Late Holocene (Turner and Plater 2004).

\subsubsection{Land-cover and land-use change}

Semi-arid savannah and shrubland ecosystems of eastern African are characterised by high spatiotemporal variability in precipitation regimes that results in a diverse ecosystem composition, structure and distribution. The Amboseli landscape has undergone a series of land-use regimes through time and currently supports pastoralists, agriculture and wildlife. The dynamic nature of the Amboseli local ecosystem is shaped by these interactions between climate, ecosystem, herbivores and humans. Pollen, non-pollen palynomorph (NPP) and charcoal data from Esambu swamp indicated that sparse woodland and shrub taxa characterised the semi-arid Amboseli landscape from c. 5000-1700 cal yr BP (Githumbi et al. 2018b) with a change from a drier environment with a small aquatic areas that expanded as regional climates become moist. Several of the published archaeological records from Amboseli (Foley 1981; Shoemaker 2018) and Kilimanjaro area (Fosbrooke and Sassoon, 1965) also published radiocarbon ages during the late Holocene or ceramic wares dated to the Holocene and suggest extensive human land uses across Amboseli (Iles et al. 2018; Odner 1971). The ecosystem was occupied by hunter-gatherer groups and subsequent pastoral Neolithic communities with regionally archaeological evidence indicating a shift in livelihood strategies with specialised pastoralism emerging $c .3000 \mathrm{cal} \mathrm{yr}$ BP (Shoemaker 2018). The Namelok record, which covers the last $c .3000$ cal yr BP, suggests the vegetation was a savannah mosaic dominated by acacias and Amarathaceae/Chenopodiaceae, Asteraceae, Cissampelos, Poaceae and Salvadora (Rucina et al. 2010). Pollen taxa recorded from 
the Lielerai-Kimana record (Figure 5) concur with the other wetland records where the dominant taxa include Vachellia (Acacia), Asteraceae, Amaranthaceae, Commiphora, Balanites and Euphorbia. The Lielerai-Kimana pollen taxa composition suggests that the landscape supported an open savannah shrubland over the last $c .1200 \mathrm{cal}$ yr BP with most of the change experienced over the last c. $500 \mathrm{cal} \mathrm{yr}$ BP. This is evident from the charcoal record (Figure 4), which shows the continued presence of fires, and low biomass consuming fires until the last 500 years where the charcoal concentration and accumulation rate triple the mean values for the whole record. The Lielerai-Kimana record shows a mix of taxa that occur at low and high elevations including Afromontane taxa such as Cordia, Podocarpus and Polyscias. This suggests that Amboseli wetlands record some of the wind-blown pollen from vegetation taxa on Kilimanjaro and Chyulu Hills.

During the Late Holocene, the Amboseli landscape has supported pastoralism and huntergatherer livelihood strategies (Lane 2004). Caravan trade routes around Kilimanjaro penetrated into Amboseli and the region was exploited for the ivory trade leading to high levels of defaunation (Håkansson 2012); notably during the 1800s and 1900s driven by high ivory prices (Håkansson 2004). The 19th century droughts and disease epidemics decimated both livestock and wild grazer populations in the region. To date, there has been no direct evidence in the archaeological records of agriculture or combination livelihoods of agro-pastoralism in Amboseli during the Late Holocene, although the absence of evidence is inconclusive and does not rule out the possibility (Githumbi et al. 2018a; Shoemaker 2018). Land uses outside of parks has placed greater pressure on protected areas as large herbivore populations increase in density. This concentration of elephants in the parks has led to a decline in woody taxa in particular in smaller parks such as Amboseli (Western et al. 2020). From the 1980s, conversion of the Amboseli wetlands for subsistence and industrial food crop agriculture was the predominant land use change (Githumbi et al. 2018b; MEMR 2012; Okello and Kioko 2011) outside of the national park.

Over the last c. $500 \mathrm{cal}$ yr BP, significant changes are observed in the Amboseli ecosystem pollen, fire and geochemical records; the physiochemical signals indicate aridity interspersed with intervals of increased moisture, which could be increased local rainfall or increased water table levels caused by increased precipitation on Kilimanjaro and Chyulu. Namelok (Rucina et al. 2010) records a dry period from c. $500 \mathrm{cal}$ yr BP indicated by the continuous presence and increase in taxa such as Vachellia (Acacia), Amaranthaceae/Chenopodiaceae, Cyperaceae and Poaceae. This is accompanied by a significant increase in charcoal levels attributed to presence of anthropogenic activity such as pastoralism and eventually agriculture at Lielerai-Kimana, Namelok and Esambu. Taxa associated with human activity are not identified from the LieleraiKimana record; however, Ricinus communis and Cannabis sativa are recorded with increasing numbers in Namelok from $c .1600$ cal yr BP (Rucina et al. 2010). The Esambu wetland records a decrease in woody taxa with increasing Cyperaceae and Poaceae, a combination of a dry interval and human presence in the savannah and surrounding highlands. The decreased charcoal content in the top $20 \mathrm{~cm}\left({ }^{210} \mathrm{~Pb}\right.$ dates of $\left.-38 \mathrm{cal} \mathrm{yr} \mathrm{BP}\right)$ is consistent with the low occurrence of fires currently on the landscape observed by satellite observations (Githumbi et al. 2018a) and the high level of grazing pressure both by cattle and wild herbivores on the grazing-dominated savannahs (Bond and Keeley 2005; van Langevelde et al. 2003).

\subsection{CONCLUSIONS}

Small tropical wetlands provide information about the local changes in a landscape. However, they have to be utilised with caution on their own due to the inability to discern the driver or scale of ecosystem change. The Lielerai-Kimana wetland allows us to visualise the general Amboseli environment, i.e. a savannah shrubland and the changes within the wetland but not the drivers of the change. Data from Lielerai-Kimana, Esambu, Enkongu, Namelok wetlands highlight the 
continued maintenance of a semi-arid savannah with varying levels of woodland. Significant social-ecological changes have occurred within the same interval that we observe the significant increase of charcoal c. $500 \mathrm{cal}$ yr BP; arrival of the Maa-speaking pastoralists into Amboseli, widespread Swahili settlement increasing, arrival of the colonialist, increased elephant poaching and more recently land management policies. These past and current land cover and land use impacts and the timing of the vegetation, sedimentary and fire regime changes across the wetlands indicate localised controls; this emphasises the differential ecosystem responses of each wetland and highlights that small wetlands can be used to corroborate regional events.

\section{ACKNOWLEDGEMENTS}

We thank Stephen Rucina, Veronica Muiruri, Rahab Kinyanjui and Rebecca Muriuki from the National Museums of Kenya, Palaeobotany and Palynology Section for field and laboratory support; Joseph Mutua and Nicholas Gakuu for fieldwork logistics; and the British Institute in Eastern Africa (Nairobi) for their continued support. We thank William Gosling, Anne-Marie Lezine and Louis Scott for their organisation of this special issue. This study contributes to the African Pollen Database (APD), Neotoma Paleoecology Database, and the PAGES supported Global Paleofire Working Group (GPWG2) and PAGES-LandCover6k. Past Global Changes (PAGES) is funded by the Swiss Academy of Sciences and Chinese Academy of Sciences and supported in-kind by the University of Bern, Switzerland. ENG and CCM were supported by a European Commission Marie Skłodowska-Curie Initial Training Network grant to RM and coordinated by Paul Lane through Uppsala University (FP7-PEOPLE-2013-ITN project number 606879). ${ }^{210} \mathrm{~Pb}$ and $\mathrm{C} / \mathrm{N}$ data presented in this paper was supported by NERC Radiocarbon Allocation 1681.1012 or funded by the Natural Environment Research Council NERC standard grant number NE/I012915/1 to Dan Charman at University of Exeter, UK, and we thank Angela Gallego-Sala and the Millipeat Project. This research formed part of the PhD dissertation of EG, University of York. In memory of our friends and colleagues, Richard Payne and Eric Grimm.

\section{REFERENCES}

Altmann, J., Alberts, S.C., Altmann, S.A., and Roy, S.B., 2002, Dramatic change in local climate patterns in the Amboseli basin, Kenya. African Journal of Ecology, 40(3), pp. 248-251, 10.1046/j.1365-2028.2002.00366.x.

Appleby, P.G., 2005, Chronostratigraphic techniques in recent sediments. In Tracking Environmental Change Using Lake Sediments: Developments in Paleoenvironmental Research, Volume 1, edited by Last W.M., Smol J.P., (Dordrecht: Kluwer Academic Publishers), pp. 171-203.

Ashley, G.M., Goman, M., Hover, V.C., Owen, R.B., Renaut, R.W. and Muasya, A.M., 2002, Artesian blister wetlands, a perennial water resource in the semi-arid Rift Valley of East Africa. Wetlands, 22(4), pp. 686-695, 10.1672/0277-5212(2002)022[0686:ABWAPW]2.0.CO;2.

Barnekow, L., Possnert, G., and Sandgren, P., 1998, AMS ${ }^{14} \mathrm{C}$ chronologies of Holocene lake sediments in the Abisko area, northern Sweden - a comparison between dated bulk sediment and macrofossil samples. GFF, 120(1), pp. 59-67.

Bennett, K.D., 1996, Determination of the number of zones in a biostratigraphical sequence. New Phytologist, 132(1), pp. 155-170, 10.1111/j.1469-8137.1996.tb04521.x.

Blaauw, M., and Christen, J.A., 2011, Flexible paleoclimate age-depth models using an autoregressive gamma process. Bayesian Analysis, 6(3), pp. 457-474, 10.1214/ba/1339616472. 
Blott, S.J., and Pye, K., 2012, Particle size scales and classification of sediment types based on particle size distributions: Review and recommended procedures. Sedimentology, 59(7), pp. 2071-2096, 10.1111/j.1365-3091.2012.01335.x.

Bond, W., and Keeley, J., 2005, Fire as a global 'herbivore': the ecology and evolution of flammable ecosystems. Trends in Ecology \& Evolution, 20(7), pp. 387-394, 10.1016/j.tree.2005.04.025.

Bonnefille, R., and Riollet, G., 1980, Pollens des savanes d'Afrique orientale. (Paris: CNRS).

Casanova, M.T., and Powling, I.J., 2015, What makes a swamp swampy? Water regime and the botany of endangered wetlands in western Victoria. Australian Journal of Botany, 62(6), pp. 469-480, 10.1071/BT14119.

Coetzee, J.A., 1967, Pollen analytical studies in eastern \& southern Africa. Palaeoecology of Africa, 3, pp. 1-146.

Courtney Mustaphi, C.J., Githumbi, E., Shoemaker, A., Degefa, A.Z., Petek, N., van der Plas, G., Muriuki, R.M., Rucina, S.M., and Marchant, R., 2014, Ongoing sedimentological and palaeoecological investigations at Lielerai Kimana and Ormakau Swamps, Kajiado District, Kenya, Report. (Kenya: Resilience in East African Landscapes Project), pp. 1-32.

Courtney Mustaphi, C.J., Davis, E.L., Perreault, J.T., and Pisaric, M.F., 2015, Spatial variability of recent macroscopic charcoal deposition in a small montane lake and implications for reconstruction of watershed-scale fire regimes. Journal of Paleolimnology, 54(1), pp. 71-86, 10.1007/s10933-015-9838-2.

Courtney Mustaphi CJ., Kinyanjui R., Shoemaker A., Mumbi C., Muiruri V., Marchant L., Rucina S., and Marchant R., 2020, A 3000-year record of vegetation changes and fire at a high-elevation wetland on Kilimanjaro, Tanzania. Quaternary Research, 99, pp. 34-62, 10.1017/qua.2020.76.

Croudace, I.W., and Rothwell, R.G., 2015, Micro-XRF Studies of Sediment Cores. In Tracking Environmental Change Using Lake Sediments, Volume 2: Physical and Geochemical Methods. (Dordrecht: Springer Netherlands).

Deocampo, D.M., 2002, Sedimentary structures generated by Hippopotamus amphibius in a lakemargin wetland, Ngorongoro Crater, Tanzania. Palaios, 17(2), pp. 212-217, 10.1669/08831351(2002)017<0212:SSGBHA $>2.0$.CO;2.

Dharani, N., 2011, Field Guide to Common Trees and Shrubs of East Africa. 1st ed. (Cape Town: Struik Publishers).

Erdtman, G., 1960, The acetolysis method-a revised description. Svensk Botanisk Tidskrift, 54, pp. 516-564.

Fægri, K., and Iversen, J., 1989, Textbook of Pollen Analysis, IV Edition, (New York: John Wiley and Sons).

Finch, J., Marchant, R., and Courtney Mustaphi, C.J., 2017, Ecosystem change in the South Pare Mountain bloc, Eastern Arc Mountains of Tanzania. The Holocene, 27(6), pp. 796-810, $10.1177 / 0959683616675937$.

Foley, R., 1981, Off-Site Archaeology and Human Adaptation in Eastern Africa:Analysis of Regional Artifact Density in the Amboseli, Southern Kenya. Cambridge Monographs in African Archaeology 3. British Archaeological Research International Series 97, 410p.

Fosbrooke, H.A., and Sassoon, H., 1965, Archaeological remains on Kilimanjaro. Tanganyika Notes and Records 64, pp. 62-64.

Gallego-Sala, A.V., Charman, D.J., Brewer, S., Page, S.E., Colin Prentice, I., Friedlingstein, P., Moreton, S., Amesbury, M.J., Beilman, D.W., Bjamp, S., Blyakharchuk, T., Bochicchio, C., Booth, R.K., Bunbury, J., Camill, P., Carless, D., Chimner, R.A., Clifford, M., Cressey, E., Courtney-Mustaphi, C., Vleeschouwer, O., Jong, R., Fialkiewicz-Koziel, B., Finkelstein, S.A., Garneau, M., Githumbi, E., Hribjlan, J., Holmquist, J., M Hughes, P.D., Jones, C., Jones, M.C., Karofeld, E., Klein, E.S., Kokfelt, U., Korhola, A., Lacourse, T., Roux, G., Lamentowicz, M., Large, D., Lavoie, M., Loisel, J., Mackay, H., MacDonald, G.M., Makila, M., Magnan, G., 
Marchant, R., Marcisz, K., Martamp, A., Cortizas, N., Massa, C., Mathijssen, P., Mauquoy, D., Mighall, T., G Mitchell, F.J., Moss, P., Nichols, J., Oksanen, P.O., Orme, L., Packalen, M.S., Robinson, S., Roland, T.P., Sanderson, N.K., Britta Sannel, A.K., Steinberg, N., Swindles, G.T., Edward Turner, T., Uglow, J., Vamp, M., Bellen, S., Linden, M., Geel, B., Wang, G., Yu, Z., Zaragoza-Castells, J., and Zhao, Y., 2018, Latitudinal limits to the predicted increase of the peatland carbon sink with warming. Nature Climate Change, 8, pp. 907-914.

Gillson, L., 2004, Testing non-equilibrium theories in savannas: 1400 years of vegetation change in Tsavo National Park, Kenya. Ecological Complexity, 1(4), pp. 281-298, 10.1016/j.ecocom.2004.06.001.

Gillson, L. and Marchant, R., 2014, From myopia to clarity: sharpening the focus of ecosystem management through the lens of paleoecology. Trends in Ecology \& Evolution, 29(6), pp. 317 325, 10.1016/j.tree.2014.03.010.

Githumbi, E.N., 2017, Holocene Environmental and Human Interactions in East Africa. PhD Thesis. University of York, UK.

Githumbi, E.N., Courtney Mustaphi, C.J., and Marchant, R., 2014, Natural and anthropogenic causes of environmental change in the Amboseli and Mau Forest regions. British Institute in Eastern Africa Annual Report 2013-2014, (Nairobi and London: British Institute in Eastern Africa), pp. 11-12.

Githumbi, E.N., Kariuki, R., Shoemaker, A., Courtney-Mustaphi, C.J., Chuhilla, M., Richer, S., Lane, P., and Marchant, R., 2018a, Pollen, people and place: Multidisciplinary perspectives on ecosystem change at Amboseli, Kenya. Frontiers in Earth Science, 5, article: 113, 10.3389/feart.2017.00113.

Githumbi, E.N., Courtney Mustaphi, C.J., Yun, K.J., Muiruri, V., Rucina, S.M., and Marchant, R., 2018b, Late Holocene wetland transgression and 500 years of vegetation and fire variability in the semi-arid Amboseli landscape, southern Kenya. Ambio, 47(6), pp. 682-696, 10.1007/s13280-018-1014-2.

Githumbi, E.N., Marchant, R., and Olago, D., 2020, Using the Past to Inform a Sustainable Future: Palaeoecological Insights from East Africa. In African and the Sustainable Development Goals. (Springer International Publishing), pp. 187-195.

Grimm, E.C., 1987, CONISS: a FORTRAN 77 program for stratigraphically constrained cluster analysis by the method of incremental sum of squares. Computers \& Geosciences, 13(1), pp. 13-35, 10.1016/0098-3004(87)90022-7.

Grimm, E.C., Maher, L.J., and Nelson, D.M., 2009, The magnitude of error in conventional bulk-sediment radiocarbon dates from central North America. Quaternary Research, 72(2), pp. 301-308, 10.1016/j.yqres.2009.05.006.

Grossmann, M., 2008. The Kilimanjaro aquifer. In: Conceptualizing Cooperation on Africa's Transboundary Groundwater Resources, Volume 32, edited by Herrfahrdt-Pähle, E. and Scheumann, W. (German Development Institute), pp. 91-124.

Håkansson, N.T., 2004, The human ecology of world systems in East Africa: The impact of the ivory trade. Human Ecology, 32(5), pp. 561-591, 10.1007/s10745-004-6097-7.

Håkansson, N.T., 2012, Ivory - Socio-ecological consequences of the East Africa ivory trade. In Ecology and Power: Struggles over Land and Material Resources in the Past, Present, and Future, edited by Hornborg, A., Clark, B. and Hermele, K., (London and New York: Routledge), pp. 124-142.

Hamilton, A.C., 1976, Identification of East African Urticales Pollen. Pollen et Spores, 18(1), pp. 27-66.

Hamilton, A.C., 1982, Environmental History of East Africa: A study of the Quaternary. (London: Academic Press).

Hamilton, A.C., and Perrott, R.A., 1980, Modern pollen deposition on a tropical African mountain. Pollen et Spores, 22(3-4), pp. 437-468. 
Heckmann, M., 2014, Farmers, smelters and caravans: Two thousand years of land use and soil erosion in North Pare, NE Tanzania. Catena, 113, pp. 187-201, 10.1016/j.catena.2013.07.010.

Heiri, O., Lotter, A.F., and Lemcke, G., 2001, Loss on ignition as a method for estimating organic and carbonate content in sediments: Reproducibility and comparability of results. Journal of Palaeolimnology, 25, pp. 101-110, 10.1023/A:1008119611481.

Hodgson, D.L., 2000, Taking Stock: State Control, Ethnic Identity and Pastoralist Development in Tanganyika. The Journal of African History, 41(1), pp. 55-78, 10.1017/S0021853799007574.

Hogg, A.G., Hua, Q., Blackwell, P.G., Niu, M., Buck, C.E., Guilderson, T.P., Heaton, T.J., Palmer, J.G., Reimer, P.J., Reimer, R.W., Turney, C.S.M., and Zimmerman, S.R.H., 2013, SHCal13 Southern Hemisphere Calibration, 0-50,000 Years cal BP. Radiocarbon, 55(4), pp. 1889-1903, 10.2458/azu_js_rc.55.16783.

Hulme, M., 1996, Climate change within the period of meteorological records. In: The physical geography of Africa, edited by Adams, W.M., Goudie, A.S. and Orme, A.R., (New York: Oxford University Press), pp. 88-102.

Iles, L., Stump, D., Heckmann, M., Lang, C., and Lane, P.J., 2018, Iron Production in North Pare, Tanzania: Archaeometallurgical and Geoarchaeological Perspectives on Landscape Change. African Archaeological Review, 35(4), pp. 507-530, 10.1007/s10437-018-9312-4.

Jolly, I.D., McEwan, K.L., and Holland, K.L., 2008, A review of groundwater-surface water interactions in arid/semi-arid wetlands and the consequences of salinity for wetland ecology. Ecohydrology, 1(1), 43-58, 10.1002/eco.6.

Jowsey, P.C., 1966, An improved peat sampler. New Phytologist, 65(2), pp. 245-248, 10.1111/j.1469-8137.1966.tb06356.x.

Juggins, S., 2003, C2 user guide: Software for ecological and palaeoecological data analysis and visualization. (Newcastle upon Tyne: University of Newcastle), pp. 1-73.

Kenya Wildlife Service, 2009, Amboseli Ecosystem Management Plan, 2008-2018. (Kenya Wildlife Service Biodiversity Planning, Assessment \& Compliance Department).

Koff, T., and Vandel, E., 2008, Spatial distribution of macrofossil assemblages in surface sediments of two small lakes in Estonia. Estonian Journal of Ecology, 57, pp. 5-20, 10.3176/eco.2008.1.01.

Lane, P.J., 2004, The 'moving frontier' and the transition to food production in Kenya. Azania, 39, pp. 243-264, 10.1080/00672700409480402.

Liutkus, C.M., and Ashley, G.M., 2003, Facies model of a semiarid freshwater wetland, Olduvai Gorge, Tanzania. Journal of Sedimentary Research, 73(5), pp. 691-705, $10.1306 / 021303730691$.

Makindi, S.M., 2016, Local communities, biodiversity conservation and ecotourism: A case study of the Kimana Community Wildlife Sanctuary, Kenya. African Journal of Hospitality, Tourism and Leisure, 5(3), pp. 1-15.

Marchant, R., Mumbi, C., Behera, S., and Yamagata, T., 2007, The Indian Ocean dipole? The unsung driver of climatic variability in East Africa. African Journal of Ecology, 45(1), pp. 4-16, 10.1111/j.1365-2028.2006.00707.x.

McCarthy, T.S., Ellery, W.N., and Bloem, A., 1998, Some observations on the geomorphological impact of hippopotamus (Hippopotamus amphibius L.) in the Okavango Delta, Botswana. African Journal of Ecology, 36(1), pp. 44-56, 10.1046/j.1365-2028.1998.89-89089.x.

Meguro, T., and Inoue, M., 2011, Conservation Goals Betrayed by the Uses of Wildlife Benefits in Community-based Conservation: The Case of Kimana Sanctuary in Southern Kenya. Human Dimensions of Wildlife, 16(1), pp. 30-44, 10.1080/10871209.2011.531516.

Meijerink, A.M.J., and Wijngaarden, W., 1997, Contribution to the groundwater hydrology of the Amboseli ecosystem, Kenya. In Groundwater/Surface Water Ecotones: Biological and Hydrological Interactions and Management Options, edited by Gibert, J., Mathieu, J. and Fournier, F., (Cambridge University Press), pp. 111-118. 
Ministry of Environment and Mineral Resources, 2012, Kenya Wetlands Atlas. (Nairobi: Government of Kenya).

Nelson, D.M., Verschuren, D., Urban, M.A., and Hu, F.S., 2012, Long-term variability and rainfall control of savanna fire regimes in equatorial East Africa. Global Change Biology, 18(10), pp. 3160-3170, 10.1111/j.1365-2486.2012.02766.x.

Öberg, H., Andersen, T.J., Westerberg, L.O., Risberg, J., and Holmgren, K., 2012, A diatom record of recent environmental change in Lake Duluti, northern Tanzania. Journal of Paleolimnology, 48(2), pp. 401-416, 10.1007/s10933-012-9615-4.

Öberg, H., Norström, E., Malmström Ryner, M., Holmgren, K., Westerberg, L.-O., Risberg, J., Eddudóttir, S.D., Andersen, T.J., and Muzuka, A., 2013, Environmental variability in northern Tanzania from AD 1000 to 1800, as inferred from diatoms and pollen in Lake Duluti. Palaeogeography, Palaeoclimatology, Palaeoecology, 374, pp. 230-241, 10.1016/j.palaeo.2013.01.021.

Odner, K., 1971, A Preliminary Report on an Archaeological Survey on the Slopes of Kilimanjaro. Azania: Archaeological Research in Africa, 6(1), pp. 131-149, 10.1080/00672707109511549.

Okello, M.M., 2005, Land use changes and human-wildlife conflicts in the Amboseli Area, Kenya. Human Dimensions of Wildlife, 10(1), pp. 19-28, 10.1080/10871200590904851.

Okello, M.M. and Kioko, J.M., 2011, A Field Study in the Status and Threats of Cultivation in Kimana and Ilchalai Swamps in Amboseli Dispersal Area, Kenya. Natural Resources, 2(4), pp. 197-211, 10.4236/nr.2011.24026.

Osipova, L., Okello, M.M., Njumbi, S.J., Ngene, S., Western, D., Hayward, M.W., and Balkenhol, N., 2018, Fencing solves human-wildlife conflict locally but shifts problems elsewhere: A case study using functional connectivity modelling of the African elephant. Journal of Applied Ecology, 55(6), pp. 2673-2684, 10.1111/1365-2664.13246.

Owen, R.B., Renaut, R.W., Hover, V.C., Ashley, G.M., and Muasya, A.M., 2004, Swamps, springs and diatoms: Wetlands of the semi-arid Bogoria-Baringo Rift, Kenya. Hydrobiologia, 518(1-3), pp. 59-78, 10.1023/B:HYDR.0000025057.62967.2c.

Reimer, P.J., Bard, E., Bayliss, A., Beck, J.W., Blackwell, P.G., Ramsey, C.B., Buck, C.E., Cheng, H., Edwards, R.L., Friedrich, M., 2013, IntCal13 and Marine13 radiocarbon age calibration curves 0-50,000 years cal BP. Radiocarbon, 55(4), pp. 1869-1887, 10.2458/azu_js_rc.55.16947.

Rinta, P., van Hardenbroek, M., Jones, R.I., Kankaala, P., Rey, F., Szidat, S., Wooller, M.J., and Heiri, O., 2016, Land use affects carbon sources to the pelagic food web in a small boreal lake. PLOS ONE, 11(8), article: e0159900, 10.1371/journal.pone.0159900.

Rucina, S.M., Muiruri, V.M., Downton, L., and Marchant, R., 2010, Late-Holocene savanna dynamics in the Amboseli Basin, Kenya. The Holocene, 20(5), pp. 667-677, $10.1177 / 0959683609358910$.

Schüler, L., and Hemp, A., 2016, Atlas of pollen, spores, and their parent taxa of Mt Kilimanjaro and tropical East Africa. Quaternary International, 425, pp. 301-386, 10.1016/j.quaint.2016.07.038.

Schüler, L., Hemp, A., and Behling, H., 2014, Relationship between vegetation and modern pollen-rain along an elevational gradient on Kilimanjaro, Tanzania. The Holocene, 24(6), 702-713, 10.1177/0959683614526939.

Shoemaker, A., 2018, Pastoral pasts in the Amboseli landscape: An archaeological exploration of the Amboseli ecosystem from the later Holocene to the colonial period. Department of Archaeology and Ancient History, PhD thesis. (Sweden: Uppsala University).

Tsakiridou, M., Cunningham, L., and Hardiman, M., 2021, Toward a standardized procedure for charcoal analysis. Quaternary Research, 99(1998), pp. 329-340, 10.1017/qua.2020.56.

Turner, S. and Plater, A., 2004, Palynological evidence for the origin and development of late Holocene wetland sediments: Mdlanzi Swamp, KwaZulu-Natal, South Africa. South African Journal of Science, 100(3-4), pp. 220-229. 
Urban, M.A., Nelson, D.M., Street-Perrott, F.A., Verschuren, D., and Hu, F.S., 2015, A late-Quaternary perspective on atmospheric $\mathrm{pCO}_{2}$, climate, and fire as drivers of $\mathrm{C}_{4}$-grass abundance. Ecology, 96(3), pp. 642-653, 10.1890/14-0209.1.

van Langevelde, F., Claudius, A.., Kumar, L., Van De Koppel, J., De Ridder, N., Van Andel, J., Skidmore, A.K., Hearne, J.W., Stroosnijder, L., Bond, W.J., Prins, H.H.T., and Rietkerk, M., 2003, Effects of fire and herbivory on the stability of savanna ecosystems. Ecology, 84(2), pp. 337-350, 10.1890/0012-9658(2003)084[0337:EOFAHO]2.0.CO;2.

Verschuren, D., Sinninghe Damsté, J.S., Moernaut, J., Kristen, I., Blaauw, M., Fagot, M., and Haug, G.H., 2009, Half-precessional dynamics of monsoon rainfall near the East African Equator. Nature, 462(7273), pp. 637-641, 10.1038/nature08520.

Western, D., 1973, The Structure, Dynamics and Changes of the Amboseli Ecosystem. PhD thesis. (Kenya: University of Nairobi).

Western, D., and Van Praet, C., 1973, Cyclical changes in the habitat and climate of an East African ecosystem. Nature, 241(5385), pp. 104-106, 10.1038/241104a0.

Western, D., Tyrrell, P., Brehony, P., Russell, S., Western, G., and Kamanga, J., 2020, Conservation from the inside out: Winning space and a place for wildlife in working landscapes. People and Nature, 2(2), pp. 279-291, 10.1002/pan3.10077.

Williams, L.A.J., 1972, Geology of the Amboseli Area. (Nairobi: Ministry of Natural Resources). Wishitemi, B.E.L., Momanyi, S.O., Ombati, B.G., and Okello, M.M., 2015, The link between poverty, environment and ecotourism development in areas adjacent to Maasai Mara and Amboseli protected areas, Kenya. Tourism Management Perspectives, 16, pp. 306-317, 10.1016/j.tmp.2015.07.003. 